\title{
Age Structure and Growth Dynamics of European Chub, Squalius cephalus, Linnaeus 1758(Actinpterygii: Cyprinidae) from two Catchments in Transylvania-Romania
}

\author{
Vioara MIREȘAN ${ }^{1}$, Călin LAȚIU ${ }^{1}$, Daniel COCAN ${ }^{1 *}$ \\ ${ }^{1}$ Faculty of Animal Science and Biotechnologies, University of Agricultural Sciences and Veterinary \\ Medicine Cluj-Napoca, 3-5 Mănăştur Street, 400372, Cluj-Napoca, Romania \\ * corresponding author: cocandaniel@yahoo.com; daniel.cocan@usamvcluj.ro
}

Bulletin UASVM Animal Science and Biotechnologies 73(2)/ 2016

Print ISSN 1843-5262; Electronic ISSN 1843-536X

DOI:10.15835/buasvmcn-asb: 12244

\begin{abstract}
In recent years, research on water monitoring involves more and more the analysis of ichtyofauna in many aspects such as: the number of fish species, their distribution in the catchment sectors, the ratio between them, the dominant species, and growth dynamics and age structure of fish populations.The chub (Squalius cephalus), is in this case an indicator species. It is present in most rivers in Romania and it is well represented numerically. The specimens for our study were collected from the Someşul Mic River (Cluj County) respectively Târnava (Alba County).Growth dynamics in this case is a comparison tool, perfect for fish populations. Age category distribution from the catchments taken into study is also a tool that gives us important information. The absence of some age categories is a question mark related to environmental accidents that occurred on a river or river sector. Through this study, we intend to demonstrate that growth dynamics and age structure are effective tools for characterizing and comparing fish populations.
\end{abstract}

Keywords: Squalius cephalus, age category, growth dynamics, different catchments

\section{INTRODUCTION}

The chub (Squalius cephalus) belongs to the Cyprinidae family, being a species widespread throughout Europe, with the exception of the Nordic countries.Before 2001, the presence of chub in Ireland inland waters has not been reported. In 2001 and 2004 the species was reported by anglers (Caffrey et. al, 2008). In Romania, it is found almost exclusively in flowing waters: trout area section of rivers and at the confluence that flow into the Danube and also in lowland streams and small rivers (Bănărescu, 1964). This species is also encountered in most reservoirs on major rivers landscaped in Romania (Cristea, 2004). The species appears very early in the pit ballast ponds resulting from the extraction of gravel or construction in areas adjacent to rivers.

It has a great capacity to adapt both in terms of diet (Balestrieri et al., 2006) and in terms of the structure of aquatic ecosystems in which they live. When it finds optimal conditions and compliant with its biological needs this species tends to become invasive to the detriment of other species (Gergely et al., 2011, Winfield et al., 2011). One of the reasons that lead to the expansion of its area is the breeding rate (Unlu and Balci 1993). Actually, the speciesis suitable even artificial breeding (Krejzeff et al., 2008). Another reason for the species to expand its area is because it has a dominant character in relation to species 
Tab. 1. Geographical data of the studied catchments

\begin{tabular}{|c|c|c|c|c|}
\hline Sampling Rivers & Altitude (m) & $\begin{array}{c}\text { Length of River } \\
(\mathrm{km})\end{array}$ & Catchment Area $\left(\mathrm{km}^{2}\right)$ & GPS Coordinates (N-E) \\
\hline Someșul Mic River & 359.97 & 376 & 3773 & $\begin{array}{l}\text { N } 46^{\circ} 45^{\prime} 45.76^{\prime \prime} \\
\text { E } 23^{\circ} 32^{\prime} 21.67^{\prime \prime}\end{array}$ \\
\hline Târnava River & 236.53 & 246 & 6253 & $\begin{array}{l}\text { N } 46^{\circ} 09^{\prime} 38.60^{\prime \prime} \\
\text { E } 23^{\circ} 52^{\prime} 38.66^{\prime \prime}\end{array}$ \\
\hline
\end{tabular}

from the new ecosystems, is the wide range of nutrition. Even though some authors (Bud et al., 2007) consider the species as a predatory one, the great variety of foods they consume rather gives an omnivorous character (Markovic, 2007). Anatomical features, such as the presence of pharyngeal teeth, specific to the Cyprinidae family members and the absence of teeth on both jaws, support this claim. Chub adapts very well to natural food resources based on natural river productivity, seasonal and ontogenesis stage. Piria et al., (2005) describe the diet correlated with age, from the simplest forms of phytoplankton (in the larval stage), to maturity when it goes to consume crustaceans, amphibians, fish, chicken or mammal.

The uniformity of chub populations and its distribution of age groups can give important information related to water quality (Kurtovic et al., 2009). In this regard, Havelkova et al., (2008) noted that aquatic organisms, including chub, are bio-indicators regarding the presence and levels of chemical pollution. In our study we monitored the chub (Squalius cephalus) population structure in two catchments: Someşul Mic River (Cluj County) and Târnava (Alba County). Populations were analyzed in terms of age structure, growth dynamics and biotic and abiotic factors that influence growth and development of this species.

\section{MATERIALS AND METHODS}

The experiments were conducted in JulySeptember 2014. From Someşul Mic River were sampled 26 specimens of 2 to 11 years. From Târnava River were sampled 38 specimens aged between 2 to 11 years (Tab. 1).

The specimens of chub (Squalius cephalus) were transported to the laboratories of Fisheries and Aquaculture at UASVM Cluj-Napoca. The method of capturing was angling.The age of specimens was determined by sclerochronology techniques, being evaluated annual growth rings on the scales. Growth rings were highlighted by
Lostunetal., (2004) technique. From each specimen were collected three scales (the left side of the fish). They were dried and then placed between glass slides, and were studied under a microscope. The microscope used was Nikon Eclipse 50 with Digital Camera and capture controller (DS and DS fi1 U2). The objectives used were: $4 \mathrm{X}, 10 \mathrm{X}$ and 40X. Somatic measurements were performed by photometry using a Nikon D90 with 15-55 lens and ToUpView-Amscope software. We also calculated Fulton condition factor (K) for each age group from the two catchments. To reduce the stress of handling, specimens were anesthetized with Eugenol - Clove Oil $(0.4 \mathrm{ml}$ Eugenol in 10L of water at $19^{\circ} \mathrm{C}$ ).

\section{RESULTS AND DISCUSSIONS}

Determining the age of the fish is an important activity in applied biological research and the collected data regarding phylogenetic and ontogenetic evolution, reaching sexual maturity, period of breeding, the age structure of the population, as well as references on water basins productivity and lifespan of individuals in a population (Maitland, 2004) can be benchmarked. From ecological and paleo-ecological point of view it is estimated the adaptive response of fish populations to natural environment pressure (climate change) (Crozier and Hutchings, 2014) or anthropogenic (fisheries, pollution, coastal development) (Franssen et al., 2012). Based on the growth rings on the scales (Fig.-1) of chub specimen collected from the two catchments (Fig. 2) age categories were determined.

From Someşul Mic River were sampled 26 specimens aged from 2 to 11 years and from Târnava River were sampled 38 specimens of ages from 2 to 11 years.

For Someşul Mic River 7+, 8+, 9+ and 10+ age categories were missing. A similar situation can be observed in the case of Târnava River age groups, where $6+, 7+, 9+$ and $10+$ were missing too. 


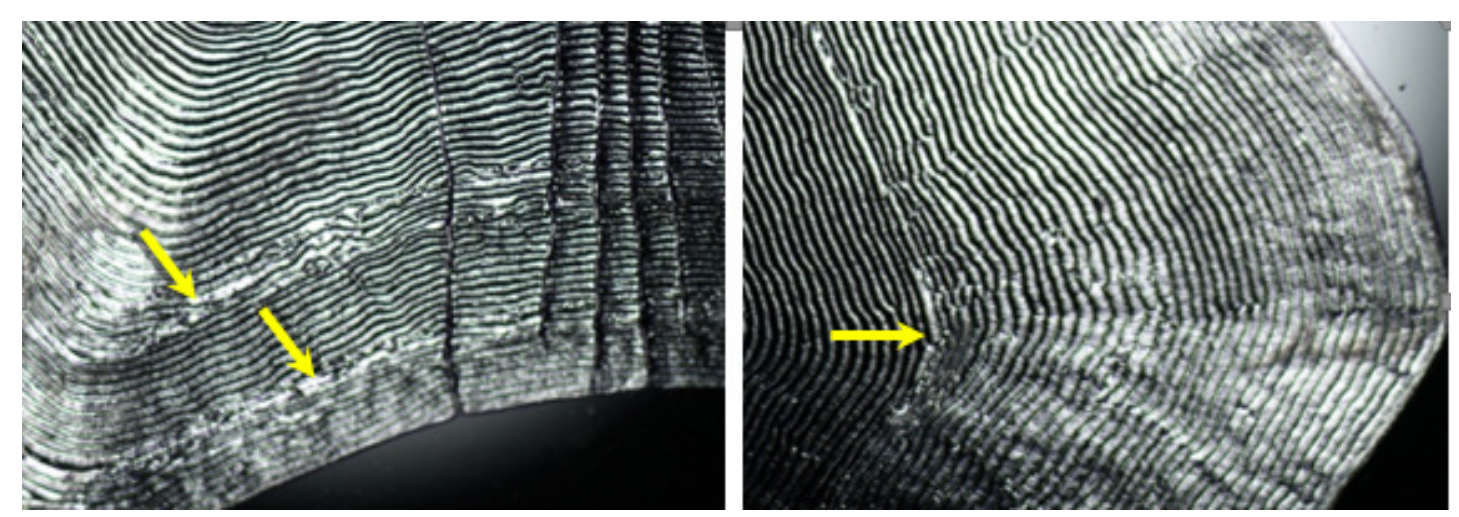

Fig.1. Inter annual growth rings on the chub scales (ob. 4X)

Someşul Mic River

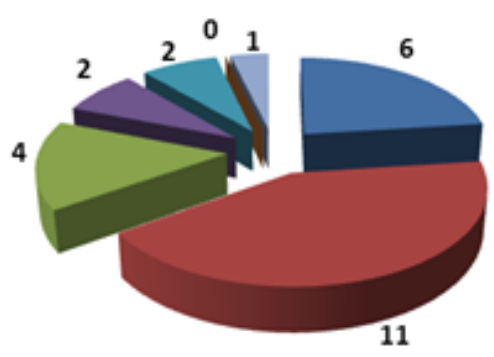

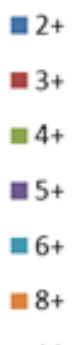

표 114
Târnava River

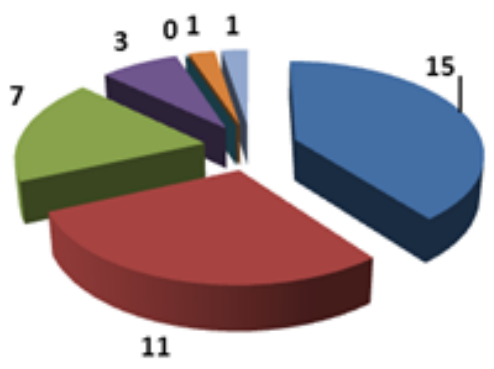

Fig.2. Age structure of chub populations from the two catchments

Natural distribution of specimens in terms of age groups for Târnava River is normal. The number of specimens decreases with age. In the case of Someșul Mic River appears an atypical difference in the $2+$ and $3+$ age groups (number of specimens of $3+$ group being greater than the number of specimens from the group 2+, 6 respectively 11 specimens).

The smallest specimen captured from Someşul Mic River was 14.00 grams and the larger was 1.097 grams. For specimens captured on Târnava River smallest specimen was 12.00 grams and the largest was 961.00 grams. The specimens were not grouped by gender. This species does not have a sexual dimorphism, except during breeding season when males develop nuptial tubercles, and capturing them was not possible because the legislation Romania is prohibiting fishing from April to July by order of prohibition.

In order to determine growth dynamics of chub in the two catchments, somatic measurements were made and are shown in tab. 2 .

Regarding the body weight (Bw), the mean value for the specimens belonging to $2+$ age category from the Someş River is higher than the mean value recorded for specimens from the Târnava River $(29.66 \mathrm{~g}$ for $\mathrm{n}=6$ vs. $27.20 \mathrm{~g}$ for $n=14)$. For the $3+$ age category, we have the same situation where the mean value for body weight is higher in favor of individuals from the Someș River (64.27g for $\mathrm{n}=11$ vs. $59.63 \mathrm{~g}$ for $\mathrm{n}=12$ ). Individuals with higher mean value of the body weight at $4+$ age category can be found on Târnava River (106.85g for $n=7$ vs. $97.50 \mathrm{~g}$ for $\mathrm{n}=4$ ). The $5+$ age category also shows higher mean values for chub specimensfrom Târnava River $(158.00 \mathrm{~g}$ for $\mathrm{n}=3$ vs. $154.50 \mathrm{~g}$ for $\mathrm{n}=2$ ). For the $6+$ age we have the mean value only for the Somes River, where were captured 2 specimens $(209.00 \mathrm{~g}$ for $\mathrm{n}=2$ ). At the $7+$ age category, both from Someș River and Târnava River were not caught any fish. One specimen for the 8+ age category of 445.00 grams was captured from Târnava River. For the 9+ and 10+ categories there were not captured any specimens. The 11+ age category there is one specimen caught for each river: a specimen of $961.00 \mathrm{~g}$ from the Târnava River and specimen of $1097.00 \mathrm{~g}$ from the Someș River. 
Tab. 2.Mean values of somatic measurements based on age class

\begin{tabular}{|c|c|c|c|c|c|c|c|c|c|c|c|c|c|}
\hline \multirow{2}{*}{ SM } & \multirow{2}{*}{ River } & \multicolumn{12}{|c|}{ Age category (years) } \\
\hline & & $\mathrm{N}$ total & $2+$ & $3+$ & $4+$ & $5+$ & $6+$ & $7+$ & $8+$ & $9+$ & $10+$ & $11+$ & 12 \\
\hline \multirow{2}{*}{$\mathrm{Bw}(\mathrm{g})$} & Someş & 26 & 29.66 & 64.27 & 97.50 & 154.50 & 209.00 & - & - & - & - & 1097.00 & - \\
\hline & Târnava & 38 & 27.20 & 59.63 & 106.85 & 158.00 & - & - & 445 & - & - & 961 & - \\
\hline \multirow{2}{*}{$\begin{array}{c}\mathrm{Tl} \\
(\mathrm{cm})\end{array}$} & Someș & 26 & 14.52 & 18.90 & 21.31 & 23.41 & 25.06 & - & - & - & - & 43.62 & - \\
\hline & Târnava & 38 & 13.95 & 17.98 & 21.39 & 24.54 & - & - & 33.43 & - & - & 33.63 & - \\
\hline \multirow{2}{*}{$\begin{array}{c}\mathrm{Sl} \\
(\mathrm{cm})\end{array}$} & Someş & 26 & 12.71 & 16.69 & 18.94 & 21.19 & 22.22 & - & - & - & - & 39.69 & - \\
\hline & Târnava & 38 & 12.17 & 15.59 & 18.76 & 21.53 & - & - & 29.50 & - & - & 29.60 & - \\
\hline \multirow{2}{*}{$\begin{array}{c}\mathrm{Hl} \\
(\mathrm{cm})\end{array}$} & Someș & 26 & 3.27 & 4.01 & 4.69 & 4.57 & 4.56 & - & - & - & - & 9.80 & - \\
\hline & Târnava & 38 & 3.20 & 3.95 & 4.43 & 5.08 & & & 5.68 & & & 7.21 & - \\
\hline \multirow{2}{*}{$\begin{array}{c}\mathrm{Cpl} \\
(\mathrm{cm})\end{array}$} & Someş & 26 & 2.47 & 3.34 & 3.67 & 4.07 & 4.18 & - & - & - & - & 7.30 & - \\
\hline & Târnava & 38 & 2.42 & 2.95 & 3.52 & 3.99 & & & 5.56 & & & 5.48 & - \\
\hline \multirow{2}{*}{$\begin{array}{c}\mathrm{H} \\
(\mathrm{cm}) \\
\end{array}$} & Someş & 26 & 2.83 & 3.78 & 4.42 & 5.22 & 6.20 & - & - & - & - & 11.29 & - \\
\hline & Târnava & 38 & 3.01 & 4.04 & 5.00 & 5.66 & & & 8.26 & & & 8.86 & - \\
\hline \multirow{2}{*}{$\begin{array}{c}\mathrm{h} \\
(\mathrm{cm})\end{array}$} & Someş & 26 & 1.27 & 1.65 & 1.92 & 2.24 & 2.36 & - & - & - & - & 4.65 & - \\
\hline & Târnava & 38 & 1.21 & 1.65 & 1.97 & 2.29 & - & - & 3.09 & - & - & 3.18 & - \\
\hline \multirow{2}{*}{$\begin{array}{c}\mathrm{Bd} \\
(\mathrm{cm})\end{array}$} & Someş & 26 & 1.87 & 2.49 & 2.95 & 3.49 & 4.11 & - & - & - & - & 7.26 & - \\
\hline & Târnava & 38 & 1.98 & 2.43 & 3.15 & 3.76 & - & - & 5.95 & - & - & 7.46 & - \\
\hline
\end{tabular}

Note: SM-somatic measurements; Bw-body weight; Tl-total lenght; Sl-standardlenght; HI-head lenght; Cpl-caudal peduncle lenght; H-maximum height; h-minimum height; Bd-body depth

Regarding the total length (TL), the Someș River registers a higher mean values for $2+$ and $3+$ age categories (with $14.52 \mathrm{~cm}$ and $18.90 \mathrm{~cm}$ ). At $4+$ and $5+$ age categories, specimens from the Târnava River have higher values (4+ with 21.39 $\mathrm{cm} ; 5+$ with $24.54 \mathrm{~cm}$ ).At the $6+$ age category we have 2 specimens captured from Someș River with a mean value of $25.06 \mathrm{~cm}$. At the $11+$ age category we have captured one specimen from each river, the higher value being measured on the specimen from the Someș River $(43.62 \mathrm{~cm})$. Regarding the standard length measurements for the specimes belonging to the $2+, 3+$ and $4+$ age categories captured from the Someș River, shows higher values than specimens from Târnava River (12.71 $\mathrm{cm}$ vs $12.17 \mathrm{~cm} ; 16.69 \mathrm{~cm}$ vs. $15.59 \mathrm{~cm}$ and 18.94 $\mathrm{cm}$ vs $18.76 \mathrm{~cm}$ ). At $5+$ age category, the higher mean value is recorded for specimens from the Târnava River $(21.53 \mathrm{~cm})$. For the Someș River the value recorded was $21.19 \mathrm{~cm}$ for this category. As can be seen in Tab. 2 age categories from $6+$ to $10+$ can not be compared because we have not caught any specimen or we have only one specimen. For the $11+$ age category the values recorded were $39.69 \mathrm{~cm}$ for the specimen captured from Somes River and $29.60 \mathrm{~cm}$ for the specimen captured from Târnava River. Head length (HL) has the same distribution of values as the standard length. Average value for the length of caudal peduncle $(\mathrm{Cpl})$ is higher for specimens from Somes River at all age categories. The maximum height $(\mathrm{H})$ shows the highest value for the specimens from the Târnava River in all age groups, except the $11+$ age category, where the higher value was recorded to the specimen captured from Somes River $(11.29 \mathrm{~cm})$. As regards the minimum height (h), we note that the 2+ age category has a higher value and is recorded for specimens from Somes River (1.27 cm vs. $1.21 \mathrm{~cm}$ - Târnava River). On $3+$ age category we have the same mean values for specimens of both rivers $(1.65 \mathrm{~cm})$. At the $5+$ and $6+$ age categories, the higher mean values were recorded for specimens from Târnava River (2.24 cm vs. $2.29 \mathrm{~cm}$ - Târnava River). At 11+ age category, the specimen from the Someș River, recorded the higher value $(4.65 \mathrm{~cm}$ vs. $3.18 \mathrm{~cm}-$ Târnava River). Body depth (Bw) shows higher values in the $2+, 4+$ and $5+$ age categories $(1.98$ $\mathrm{cm}, 3.15 \mathrm{~cm}$ and $3.76 \mathrm{~cm}$ ) for specimens from the Târnava River. The higher value recorded for Someș River is for 3+ age category. For the 11+ age category, the higher value was registered for the specimen captured from Târnava River $(7.46 \mathrm{~cm})$. 
Tab. 3. Annual growth rate of chub from the two catchments

\begin{tabular}{|c|c|c|c|c|c|c|c|c|c|c|c|}
\hline \multirow{2}{*}{ SM } & \multirow{2}{*}{ River } & \multicolumn{10}{|c|}{ Years of life } \\
\hline & & $2-3$ & $3-4$ & $4-5$ & $5-6$ & $6-7$ & $7-8$ & $8-9$ & $9-10$ & $10-11$ & $11-12$ \\
\hline \multirow{2}{*}{$\mathrm{Bw}(\mathrm{g})$} & Someș & 34.61 & 33.23 & 57.00 & 54.50 & - & - & - & - & - & - \\
\hline & Târnava & 32.43 & 47.22 & 51.15 & - & - & - & - & - & - & - \\
\hline \multirow{2}{*}{$\begin{array}{c}\mathrm{Tl} \\
(\mathrm{cm})\end{array}$} & Someș & 4.38 & 2.41 & 2.10 & 1,65 & - & - & - & - & - & - \\
\hline & Târnava & 4.03 & 3.41 & 3.15 & - & - & - & - & - & - & - \\
\hline \multirow{2}{*}{$\begin{array}{c}\mathrm{Sl} \\
(\mathrm{cm})\end{array}$} & Someș & 3.98 & 2.25 & 2.25 & 1.03 & - & - & - & - & - & - \\
\hline & Târnava & 3.42 & 3.17 & 2.77 & - & - & - & - & - & - & - \\
\hline \multirow{2}{*}{$\begin{array}{c}\mathrm{Hl} \\
(\mathrm{cm})\end{array}$} & Someș & 0.74 & 0.68 & -0.12 & -0.01 & & & & & & \\
\hline & Târnava & 0.75 & 0.48 & 0.65 & - & - & - & - & - & - & - \\
\hline \multirow{2}{*}{$\begin{array}{c}\text { Cpl } \\
(\mathrm{cm})\end{array}$} & Someș & 0.87 & 0.33 & 0.40 & 0.11 & - & - & - & - & - & - \\
\hline & Târnava & 0.53 & 0.57 & 0.47 & - & - & - & - & - & - & - \\
\hline \multirow{2}{*}{$\begin{array}{c}\mathrm{H} \\
(\mathrm{cm})\end{array}$} & Someș & 0.95 & 0.64 & 0.80 & 0.98 & - & - & - & - & - & - \\
\hline & Târnava & 1.03 & 0.96 & 0.66 & - & - & - & - & - & - & - \\
\hline \multirow{2}{*}{$\begin{array}{c}\mathrm{h} \\
(\mathrm{cm})\end{array}$} & Someş & 0.38 & 0.27 & 0.32 & 0.12 & & & & & & \\
\hline & Târnava & 0.44 & 0.32 & 0.32 & - & - & - & - & - & - & - \\
\hline \multirow{2}{*}{$\begin{array}{c}\mathrm{Bd} \\
(\mathrm{cm})\end{array}$} & Someş & 0.62 & 0.46 & 0.54 & 0.62 & - & - & - & - & - & - \\
\hline & Târnava & 0.45 & 0.72 & 0.61 & - & - & - & - & - & - & - \\
\hline
\end{tabular}

Note: SM - somatic measurements; Bw - body weight; Tl - total lenght; Sl - standard lenght; Hl - head lenght; $\mathrm{Cpl}$ - caudal peduncle lenght; $\mathrm{H}$ - maximum height; $\mathrm{h}$ - minimum height; $\mathrm{Bd}$ - body depth

Annual growth rate varies from one age category to another and from one river to the other. In terms of body weight, we observe a higher growth rate for 2-3 year range from specimen scaught in the Someș River (34.61 g vs. $32.43 \mathrm{~g}$ ). For the 3-4 year range, the higher value is favorable for specimens from the Târnava River (44.72 g vs. $33.23 \mathrm{~g}$ ). The 4-5 year range is favorable for the Someș River ( $57.00 \mathrm{~g}$ vs. $51.15 \mathrm{~g}$ ). For the remaining categories we were not able to make comparisons because of the lack of specimens.

The annual growth rate for the total length is higher at specimens from Someș River only for the 2-3 year range $(4.38 \mathrm{~cm}$ vs. $4.03 \mathrm{~cm})$. We have the same situation for standard length (SL). Measurements for head length $(\mathrm{Hl})$ indicate that growth rate is similar to the 2-3 year range for both rivers $(0.74 \mathrm{~cm}$ for Someș River and 0.75 for Târnava River). The 3-4 year range for the length of the head is in favor of specimens from the Somes River $(0.68 \mathrm{~cm}$ vs. $0.48 \mathrm{~cm})$.

It is found that, in terms of head length $(\mathrm{Hl})$, annual growth rate shows negative values. So, for specimens of chub on the Somes River, the growth is more evident in terms of body weight, comparative with the length.
The annual growth rate for the length of caudal peduncle $(\mathrm{Cpl})$ is favorable for Somes, River for the $2-3$ year range $(0.87 \mathrm{~cm}$ vs. $0.53 \mathrm{~cm})$. The 3-4 and 4-5 year, ranges for the growth rate of caudal peduncle length is higher in specimens from Târnava River. The growth rate of maximum height $(\mathrm{H})$ is favorable for 2-3 and 3-4 year ranges for specimens from the Târnava River and for the 4-5 year range the higher values were recorded for Someș River.

The growth rate for the minimum height (h) is favorable for specimens from the Târnava Riverbelonging to 2-3 year range and 3-4 year range. The 4-5 year range recorded the same values $(0.32 \mathrm{~cm})$. As regards the growth rate of body depth $(\mathrm{Bd})$, higher values were recorded for 2-3 year range for specimens from the Somes, River $(0.62 \mathrm{~cm})$ and for $3-4$ year range for the specimens from the Târnava River $(0.72 \mathrm{~cm})$ and 4-5 $(0.61 \mathrm{~cm})$.

\section{CONCLUSION}

The analysis of age category structure and the dynamic growth represents two essential tools for the characterization of fish populations. The structure of age groups provides important 
information on the distribution, presence or absence of individuals in a population.The dynamics of growth is closely linked to water quality, biotic or abiotic factors. It can be seen from the data tabulated above that specimens from the the Someş River have the head length $(\mathrm{Hl})$ and caudal peduncle length $(\mathrm{Cpl})$ longer than the specimens from the Târnava River. This is closely related to body size of specimens. The chub specimens from the Someș River have a slightly elongated body compared to chub specimens from Târnava River. Also it can be noticed that some age categories are missing on both rivers. We attribute the lack of specimens of $7+, 9+, 10+$ age categories to events of ecological nature (floods, water discharges, or the presence of dams).The chub is the dominant species on both catchments and is evenly represented. Younger specimens $(2+$, $3+, 4+)$ are present in greater numbers. Larger specimens, from the $11+$ age category are rare. This is due to a combination of anthropogenic factors. Among them: changing flows and volumes of water by dams, punctiform source discharges of chemicals in industrial areas, lack of sanitation activities of riverbanks, recreational fishing and the legal framework within which it is conducted.

\section{REFERENCES}

1. Balestrieri A, Prigioni C, Remonti L, Sgrosso S, Priore G (2006). Feeding ecology of Leuciscus cephalus and Rutilus rubilio in Southern Italy. Italian Journal of Zoology, 73:129-135.

2. Bănărescu P (1964). Fauna R. P. Romîne, Vol. 13 Pisces Osteichthyes. Ed. Academiei Republicii Populare Romîne, București.

3. Bud I, Vlădău V, Ștefan R (2007). Peştii răpitori, creştere, înmulțire, valorificare. Editura Ceres, București.

4. Caffrey JM, Acevedo S, Gallagher K, Britton R (2008). Chub (Leuciscus cephalus): a new potentially invasive fish species in Ireland. Aquatic Invasions, 3(2): 201-209.

5. Cristea IT (2004). Evaluarea ariei de repartiție a cleanului mare (Leuciscus cephalus Linnaeus, 1758) şi a unor specii (Leuciscus borysthenicus Kessler, Leuciscus souffia Risso,
Leuciscus leuciscus Linnaeus, Leuciscus idus Linnaeus) din subgenuri înrudite în România. Anale ICAS, 47: 275-284.

6. Crozier LG, Hutchings JA (2014). Plastic and Evolutionary Response to Climate Change in Fish. Evolutionary Applications, 7(1): 68-87.

7. Franssen NR, Harris J, Clark SR, Schaefer F, Stewart LK (2012). Shared and Unique Morphological Responses of Stream Fishes to Anthropogenic Habitat Alteration. Proceedings of The Royal Society - Biological Sciences, 280: 20122715.

8. Gergely I, Romocea JE, Oprea L, Sion C, Călin PG (2011). The influence of structural changes and ichtyofauna abundance on the ecological state of the Crisuri Hydrographic Area. AACL Bioflux, 4(2): 170-179.

9. Havelkova M, Blahova J, Kroupova H, Randak T, Slatinska I, Leontovycova D, GrabicR, Pospisil R, Svobodova Z (2008). Biomarkers of contaminant exposure in chub (Leuciscus cephalusL.) - biomonitoring of major rivers in the Czech Republic. Sensors 8: 2589-2603.

10. Krejszeff S, Kucharczyk D, Kupren K, Targońska K, Mamcarz A, Kujawa R, KaczkowskiZ, Ratajski S (2008). Reproduction of chub, Leuciscus cephalus L., under controlledconditions. Aquaculture Research. 39: 907-912.

11. Kurtović B, Vardić I, Valić D, Kapetanović D, Teskeredžić Z, Teskeredžić E (2009). Health status of chub (Squalius cephalus) in relation to water quality of Sava River. Croatian Journal of Fisheries, 67(2): 63-75.

12. Lostun L, Turliu N, David M (2004). Heleșteie - Piscicultura Practică. Ed. Arieşul, Satu-Mare.

13. Maitland PS (2004). Evaluating the Ecologica land Conservation Status of Freshwater Fish Communities in the United Kingdom. Scottish Natural Heritage Commissioned Report No. 001 (ROAME No. F01AC6).

14. Markovic G (2007). A contribution to data on chub (Leuciscus cephalus L., Cyprinidae, Pisces) diet in river conditions. Acta Agriculturae Serbica, XII(24): 13-18.

15. Piria M, Treer T, Aničić I, Safner R, Odak T (2005). The Natural Diet of Five Cyprinid Fish Species. Agriculturae Conspectus Scientificus, 70(1): 21-28.

16. Ünlü E. Balci K (1993). Reproductive features of Leuciscus cephalus orientalis (Normdan, 1840)from Savur Stream. Turkish Journal of Zoology, 17: 91-102.

17. Winfield IJ, Fletcher JM, James JB (2011). Invasive fish species in the largest lakes of Scotland, Northern Ireland, Wales and England: the collective UK experience. Hydrobiologia, 660(1): 93-103. 